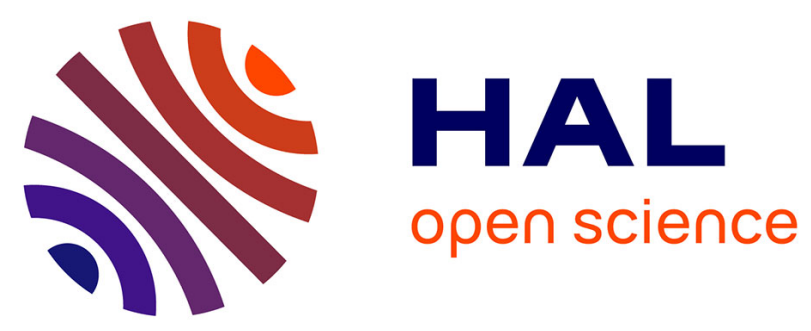

\title{
Formation and Structure of a Platinum(II) Complex Containing Two trans Nonstabilized Phosphorus Ylide Ligands: Evidence for Reversible Ylide Dissociation
}

Pavel Dub, Aurélien Béthegnies, Jean-Claude Daran, Rinaldo Poli

\section{- To cite this version:}

Pavel Dub, Aurélien Béthegnies, Jean-Claude Daran, Rinaldo Poli. Formation and Structure of a Platinum(II) Complex Containing Two trans Nonstabilized Phosphorus Ylide Ligands: Evidence for Reversible Ylide Dissociation. Organometallics, 2012, 31 (8), pp.3081-3086. 10.1021/om2012453 . hal-02909762

\section{HAL Id: hal-02909762 \\ https://hal.science/hal-02909762}

Submitted on 2 Mar 2021

HAL is a multi-disciplinary open access archive for the deposit and dissemination of scientific research documents, whether they are published or not. The documents may come from teaching and research institutions in France or abroad, or from public or private research centers.
L'archive ouverte pluridisciplinaire HAL, est destinée au dépôt et à la diffusion de documents scientifiques de niveau recherche, publiés ou non, émanant des établissements d'enseignement et de recherche français ou étrangers, des laboratoires publics ou privés. 


\section{Formation and Structure of a Platinum(II) Complex Containing two}

trans non Stabilized Phosphorus Ylide Ligands: Evidence for

\section{Reversible Ylide Dissociation}

Pavel A. Dub, ${ }^{\mathrm{a}, \mathrm{b}}$ Aurélien Béthegnies, ${ }^{\mathrm{a}, \mathrm{b}}$ Jean-Claude Daran ${ }^{\mathrm{a}, \mathrm{b}}$ and Rinaldo Poli ${ }^{\mathrm{a}, \mathrm{b}, \mathrm{c} *}$

${ }^{a}$ CNRS; LCC (Laboratoire de Chimie de Coordination); 205, route de Narbonne, BP 44099, F-

31077 Toulouse, France; Fax: (+) 33-561553003; E-mail: poli@lcc-toulouse.fr

${ }^{b}$ Université de Toulouse, UPS, INPT, F-31077 Toulouse Cedex 4, France

'Institut Universitaire de France, 103, bd Saint-Michel, 75005 Paris, France 


\section{Abstract}

The reaction of $\left(n \mathrm{Bu}_{4} \mathrm{P}\right)_{2}\left[\mathrm{PtBr}_{4}\right]$ with $2,2^{\prime}-\left(\mathrm{C}_{6} \mathrm{H}_{4} \mathrm{Li}\right)_{2}$ yields selectively (by ${ }^{195} \mathrm{Pt}$ and ${ }^{31} \mathrm{P}$

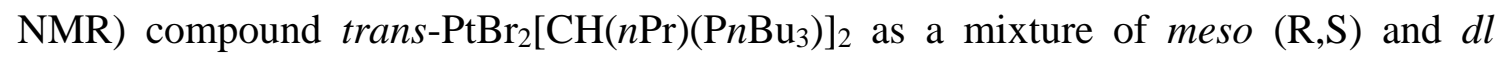
$(\mathrm{R}, \mathrm{R}+\mathrm{S}, \mathrm{S})$ diastereoisomers. The initially formed 1:1 mixture slowly evolves toward a solution richer in the meso compound, which then crystallizes selectively. In addition to the NMR characterization, the meso isomer has also been characterized by a single crystal X-ray diffraction analysis. DFT calculations in the gas phase and in solution (THF) confirm the slight thermodynamic preference for the meso isomer and reproduce the chemical shift difference of the ${ }^{195} \mathrm{Pt}$ NMR resonances. They also suggest the likelihood of a dissociative mechanism for the slow diastereoisomer interconversion.

\section{Introduction}

We have recently carried out synthetic and solution equilibrium studies involving a few tetra- $n$-butylphosphonium salts of anionic platinate(II) complexes, including $\left[n \mathrm{Bu}_{4} \mathrm{P}\right]_{2}\left[\mathrm{PtBr}_{4}\right],\left[n \mathrm{Bu}_{4} \mathrm{P}\right]_{2}\left[\mathrm{Pt}_{2} \mathrm{Br}_{6}\right],\left[n \mathrm{Bu}_{4} \mathrm{P}\right]\left[\mathrm{PtBr}_{3}\left(\mathrm{PhNH}_{2}\right)\right]$ and $\left[n \mathrm{Bu}_{4} \mathrm{P}\right]\left[\mathrm{PtBr}_{3}\left(\mathrm{C}_{2} \mathrm{H}_{4}\right)\right] .{ }^{1}$ These and other neutral derivatives, namely cis- and trans- $\mathrm{PtBr}_{2}\left(\mathrm{PhNH}_{2}\right)\left(\mathrm{C}_{2} \mathrm{H}_{4}\right)$ and cis$\mathrm{PtBr}_{2}\left(\mathrm{PhNH}_{2}\right)_{2}$ are low-energy intermediates of the catalytic intermolecular 
hydroamination of ethylene by aniline. ${ }^{1-7}$

In an attempt to generate a diaryl derivative of type $\left[\mathrm{Ar}_{2} \mathrm{PtBr}_{2}\right]^{2-}$, which we wished to test for its potential as a hydroamination pre-catalyst, we have reacted a solution of $\left[n \mathrm{Bu}_{4} \mathrm{P}\right]_{2}\left[\mathrm{PtBr}_{4}\right]$ with a lithium aryl derivative, $2,2^{\prime}-\left(\mathrm{C}_{6} \mathrm{H}_{4} \mathrm{Li}\right)_{2}$. The reaction, however, led to deprotonation of the phosphonium cation and to the isolation of an unprecedented bis(ylide) derivative of platinum(II). The reaction leading to the formation of this product and its structural characterization are reported herein.

\section{Experimental section}

General. The synthesis was carried out under argon. THF and $\mathrm{Et}_{2} \mathrm{O}$ were dried by conventional methods and distilled under argon prior to use. NMR investigations were carried out on Bruker DPX 300 spectrometer operating at $64.5 \mathrm{MHz}\left({ }^{195} \mathrm{Pt}\right)$ and 121.49 $\mathrm{MHz}\left({ }^{31} \mathrm{P}\left\{{ }^{1} \mathrm{H}\right\}\right)$. The spectra were calibrated relative to external $\mathrm{Na}_{2} \mathrm{PtCl}_{6}\left({ }^{195} \mathrm{Pt}\right)$ or $85 \%$ $\mathrm{H}_{3} \mathrm{PO}_{4}\left({ }^{31} \mathrm{P}\right)$.

\section{Generation and crystallization of complex trans-(R,S)-PtBr2 $[\mathrm{CH}(n \mathrm{Pr})-$}

$(\mathbf{P n B u})]_{2}$. To a cooled solution $\left(-70^{\circ} \mathrm{C}\right)$ of $2,2^{\prime}-\left(\mathrm{C}_{6} \mathrm{H}_{4} \mathrm{Br}\right)_{2}(36 \mathrm{mg}, 0.116 \mathrm{mmol})$ in $\mathrm{Et}_{2} \mathrm{O}$ (2 mL) was added dropwise BuLi (0.16 mL of a 1.6 M hexane solution, 2.2 equiv). After stirring at $-70^{\circ} \mathrm{C}$ for $5 \mathrm{~min}$, this solution was transferred by cannula dropwise at - 
$70^{\circ} \mathrm{C}$ into a separate Schenk flask where a suspension of $\left[n \mathrm{Bu}_{4} \mathrm{P}\right]_{2}\left[\mathrm{PtBr}_{4}\right](100 \mathrm{mg}$, $0.097 \mathrm{mmol}$ ) in $3 \mathrm{ml}$ of THF had been separately prepared. Subsequent warming to room temperature resulted in a clear yellow solution. After stirring for $1 \mathrm{~h}$ at r.t., a portion of the solution was withdrawn and used to measure a ${ }^{195} \mathrm{Pt}\left\{{ }^{1} \mathrm{H}\right\}$ NMR spectrum with overnight data collection (external lock with a $\mathrm{C}_{6} \mathrm{D}_{6}$ capillary). The spectrum showed only two broad resonances with equal intensity at $\delta-3471$ and -3482 . After one additional day of stirring, a second aliquot was measured in the same way, yielding an increased intensity for the resonance at $\delta-3471$ and a decreased intensity for that at $\delta$ 3482. Yellow crystals were grown directly on the walls of this Schlenk flask by slow solvent evaporation under argon flow (ca. 2 hrs). One of these crystals was used for the $\mathrm{X}$-ray structural analysis, revealing the meso $(\mathrm{R}, \mathrm{S})$ stereochemistry. NMR $\left(\mathrm{CDCl}_{3}\right.$, 298K): ${ }^{31} \mathrm{P}\left\{{ }^{1} \mathrm{H}\right\}: 31.8\left(\mathrm{~s}+\mathrm{Pt}\right.$ satellites, $\left.{ }^{2} \boldsymbol{J}_{\mathrm{P}-\mathrm{Pt}}=60 \mathrm{~Hz}\right) ;{ }^{195} \mathrm{Pt}\left\{{ }^{1} \mathrm{H}\right\}:-3465 \mathrm{ppm}\left(\mathrm{t},{ }^{2} \boldsymbol{J}_{\mathrm{Pt}-\mathrm{P}}=\right.$ $60 \mathrm{~Hz})$

In a separate experiment run under the same conditions, the reaction was monitored by ${ }^{31} \mathrm{P}\left\{{ }^{1} \mathrm{H}\right\}$ NMR. After one hour, $0.2 \mathrm{~mL}$ of the reaction mixture diluted into $0.3 \mathrm{~mL}$ of $\mathrm{CDCl}_{3}$ revealed only one broad resonance at $\delta 31.0$ with visible Pt satellites having $\mathrm{J}_{\mathrm{PPt}} \sim 60 \mathrm{~Hz}$ (see SI, Figure $\mathrm{S} 1$ ). The shape of this spectrum did not change over 3 weeks, except for the appearance of small resonances attributed to degradation 
products. The solution was worked up by addition of wet $\mathrm{Et}_{2} \mathrm{O}$ followed by filtration of the resulting white precipitate and evaporating to dryness. The ${ }^{31} \mathrm{P}\left\{{ }^{1} \mathrm{H}\right\}$ spectrum of the yellow crude product in acetone- $d_{6}$ revealed two major resonances as closely spaced broad singlets at $\delta 31.64$ and 31.47 (relative intensity ca. 70:30), in addition to other less intense resonances attributed to decomposition products (Figure S2). An analytically pure product could not be isolated.

X-ray diffractometric analysis. A single crystal was mounted under inert perfluoropolyether at the tip of a glass fibre and cooled in the cryostream of a Bruker APEXII CCD diffractometer. The data were collected using the monochromatic MoK $\alpha$ radiation $(\lambda=0.71073)$. The structure was solved by direct methods $\left(\operatorname{SIR}^{8} 7^{8}\right)$ and refined by least-squares procedures on $F^{2}$ using SHELXL97. ${ }^{9}$ All $\mathrm{H}$ atoms attached to carbon were introduced at idealised positions and treated by the riding model. The drawing of the molecule was realised with the help of ORTEP32. ${ }^{10}$ Crystal data and refinement parameters are shown in Table 1. Crystallographic data (excluding structure factors) have been deposited with the Cambridge Crystallographic Data Centre as supplementary publication no. CCDC 857952. Copies of the data can be obtained free of charge on application to the Director, CCDC, 12 Union Road, Cambridge CB2 1EZ, UK (fax: (+44) 1223-336-033; e-mail: deposit@ @cdc.cam.ac.uk). 
Table 1. Crystal data and structure refinement parameters.

\begin{tabular}{|c|c|}
\hline Identification code & trans $-(\mathrm{R}, \mathrm{S})-\mathrm{PtBr}_{2}\left[\mathrm{CH}(n \mathrm{Pr})\left(\mathrm{P} n \mathrm{Bu}_{3}\right)\right]_{2}$ \\
\hline Empirical formula & $\mathrm{C}_{32} \mathrm{H}_{70} \mathrm{Br}_{2} \mathrm{P}_{2} \mathrm{Pt}$ \\
\hline Formula weight & 871.70 \\
\hline Temperature, $\mathrm{K}$ & 293(2) \\
\hline Wavelength & 0.71073 \\
\hline Crystal system & Triclinic \\
\hline Space group & $\mathrm{P}-1$ \\
\hline $\mathrm{a}, \AA$ & $9.5724(5)$ \\
\hline $\mathrm{b}, \AA$ & $9.8981(6)$ \\
\hline $\mathrm{c}, \AA$ & $10.3109(5)$ \\
\hline$\alpha,^{\circ}$ & $99.468(3)$ \\
\hline$\beta,^{\circ}$ & $94.966(3)$ \\
\hline$\gamma,{ }^{\circ}$ & $101.819(3)$ \\
\hline Volume, $\AA^{3}$ & $935.86(9)$ \\
\hline $\mathrm{Z}$ & 1 \\
\hline Density (calculated), $\mathrm{Mg} / \mathrm{m}^{3}$ & 1.547 \\
\hline Absorption coefficient, $\mathrm{mm}^{-1}$ & 5.987 \\
\hline $\mathrm{F}(000)$ & 440 \\
\hline Crystal size, $\mathrm{mm}^{3}$ & $0.53 \times 0.50 \times 0.10$ \\
\hline Theta range, ${ }^{\circ}$ & 3.29 to 26.02 \\
\hline Reflections collected & 7913 \\
\hline Independent reflections $\left(\mathrm{R}_{\text {int }}\right)$ & $3490(0.0718)$ \\
\hline Completeness, $\%$ & 94.7 \\
\hline Absorption correction & Semi-empirical from equivalents \\
\hline Max. and min. transmission & 0.541 and 0.053 \\
\hline Refinement method & $\mathrm{F}^{2}$ \\
\hline Data / restraints / parameters & 3490 / 0 / 167 \\
\hline Goodness-of-fit on $\mathrm{F}^{2}$ & 1.088 \\
\hline $\mathrm{R} 1, \mathrm{wR} 2[\mathrm{I}>2 \sigma(\mathrm{I})]$ & $0.0642,0.1641$ \\
\hline R1, wR2 (all data) & $0.0780,0.1771$ \\
\hline Residual density, e. $\AA^{-3}$ & 5.253 and -3.364 \\
\hline
\end{tabular}


Computational details. Computations were carried out using the hybrid Becke functional (B3) ${ }^{11,12}$ for electron exchange and the correlation functional of Lee, Yang, and Parr (LYP), ${ }^{13}$ as implemented in the GAUSSIAN 09 software package. ${ }^{14}$ For platinum, the SDD basis set with the associated effective core potential was employed. ${ }^{15}$ All other atoms were modelled at the 6-31G+(d) level of theory. Geometry optimizations were carried out on full models without system simplifications of the isolated molecules in the gas phase as well as in the tetrahydrofuran force field using the self-consistent reaction field (SCRF) with CPCM-UFF solvation model. In both cases, the identity of the optimized geometry as local energy minima was verified by frequency calculations under the harmonic approximation. NMR shielding tensors were computed with the the Gauge-Independent Atomic Orbital (GIAO) method. ${ }^{16}$

\section{Results and Discussion}

The reaction between $\left[n \mathrm{Bu}_{4} \mathrm{P}_{2}\left[\mathrm{PtBr}_{4}\right]\right.$ and $2,2^{\prime}-\left(\mathrm{C}_{6} \mathrm{H}_{4} \mathrm{Li}\right)_{2}$ in a $1: 1$ ratio was intended to yield a 2,2'-biphenyldiyl platinum(II) derivative. However, the reaction produced instead a mixture of two compounds, of which the major one was shown to correspond to the bis(ylide) derivative trans-(R,S)- $\operatorname{PtBr}_{2}\left[\mathrm{CH}(n \operatorname{Pr})\left(\mathrm{P} n \mathrm{Bu}_{3}\right)\right]_{2}$, see Scheme 
1 as confirmed by an X-ray structural analysis (vide infra). The reaction initially gave the two compounds in a 1:1 ratio, as shown by the relative intensity of their ${ }^{195} \mathrm{Pt}$ resonances at $\delta-3471$ and -3482 . Subsequently, the more upfield shifted resonance decreased very slowly (over several days) in favour of the other resonance. However, the ${ }^{31} \mathrm{P}\left\{{ }^{1} \mathrm{H}\right\}$ NMR of the reaction mixture (after diluted into $\mathrm{CDCl}_{3}$ ) revealed only one broad resonance with Pt satellites at $\delta 31.0$, see Figure S1, showing that the chemical environment around the $\mathrm{P}$ nucleus in the two compounds is very similar. The two products could be distinguished in the ${ }^{31} \mathrm{P}$ spectrum only when the crude isolated product was redissolved in acetone- $d_{6}$ (Figure S2).

A few attempts were made to generate the bis(ylide) compound by using $n \mathrm{BuLi}$ as a base. Although evidence for the formation of the same two products was obtained, this reaction led to multiple products according to the NMR analysis. The procedure using $2,2^{\prime}-\left(\mathrm{C}_{6} \mathrm{H}_{4} \mathrm{Li}\right)_{2}$, on the other hand, is selective leading to the formation of the two bis(ylide) isomers only, according to NMR. The outcome of this reaction suggests that the combination of the strong basicity of the lithium reagent and the relative acidity of the $\alpha-\mathrm{CH}_{2}$ protons in the $n \mathrm{Bu}_{4} \mathrm{P}^{+}$cations results in deprotonation to generate a phosphorus ylide intermediate, $n \mathrm{Bu} 3 \mathrm{P}=\mathrm{CH}(n \mathrm{Pr})$, which then undergoes ligand substitution at $\left[\mathrm{PtBr}_{4}\right]^{2-}$ to yield the trans-bis(ylide) product. This hypothesis seems 
confirmed by the observation, at the beginning of the reaction carried out with $n \mathrm{BuLi}$, of a strong ${ }^{31} \mathrm{P}$ NMR signal without $\mathrm{Pt}$ satellites at $9 \mathrm{ppm}$, close to the position reported for the methylene trimethylphosphorane, $\mathrm{Me}_{3} \mathrm{P}=\mathrm{CH}_{2}(2.1 \mathrm{ppm}) .{ }^{17}$ This mechanistic hypothesis immediately suggests the nature of the second product as the $d l(\mathrm{R}, \mathrm{R}+\mathrm{S}, \mathrm{S})$ diasteroisomer, consistent with the very similar NMR properties $\left({ }^{195} \mathrm{Pt},{ }^{31} \mathrm{P}\right.$ chemical shifts) of both compounds.
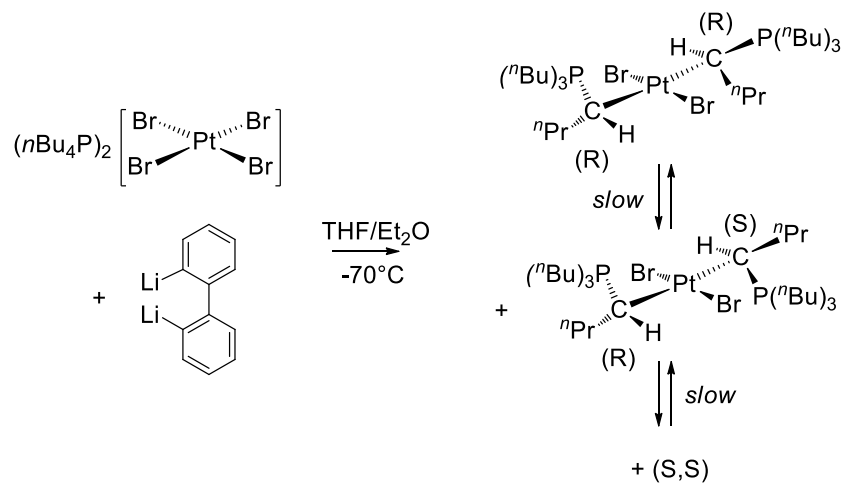

Scheme 1. Generation of the isomeric bis(ylide) $\mathrm{Pt}^{\mathrm{II}}$ complexes by the reaction of $\left[n \mathrm{Bu}_{4} \mathrm{P}\right]_{2}\left[\mathrm{PtBr}_{4}\right]$ with $2,2^{\prime}-\left(\mathrm{C}_{6} \mathrm{H}_{4} \mathrm{Li}\right)_{2}$.

Platinum(II) chemistry with phosphorus ylides is well established, but the reaction reported here shows unusual features. The substitution of halide ligands by phosphorus ylides is relatively common for stabilized ylides, such as $\mathrm{RCOCH}=\mathrm{PPh}_{3}(\mathrm{R}=\mathrm{Ph}, \mathrm{Me}$, EtO) in the case of palladium complexes. ${ }^{18}$ When the ylide is not stabilized as in the present case, and even for stabilized ylides in the case of platinum complexes, the 
reaction typically proceed with transylidation or ortho-metallation and formation of a chelating anionic ylide complex and a phosphonium salt, for instance $\mathrm{PtCl}_{2}\left(\mathrm{PMe}_{3}\right)_{2}$ and two equivalents of $t \mathrm{Bu}_{2} \mathrm{MeP}=\mathrm{CH}_{2}$ yield $\left[\mathrm{Pt}\left\{\left(\mathrm{CH}_{2}\right)_{2} \mathrm{P} t \mathrm{Bu}_{2}\right\}\left(\mathrm{PMe}_{3}\right)_{2}\right]^{+} \mathrm{Cl}^{-}$and $t \mathrm{Bu}_{2} \mathrm{Me}_{2} \mathrm{P}^{+} \mathrm{Cl}^{-19}$ In the latter reaction, the second equivalent of ylide captures a proton from an $\alpha-\mathrm{C}-\mathrm{H}$ bond of the already coordinated ylide ligand. The reaction between $\mathrm{PtCl}_{2}$ and $\mathrm{Ph}_{3} \mathrm{P}=\mathrm{CHCOCH}_{3}$ was initially incorrectly described as leading to the bis(ylide) adduct but was later shown to yield the ortho-metallation product $[\mathrm{Pt}(\mu-\mathrm{Cl})(o$ $\left.\left.\mathrm{C}_{6} \mathrm{H}_{4} \mathrm{PPh}_{2} \mathrm{CHCOCH}_{3}\right)\right]_{2}{ }^{20,21}$ For the reaction presented herein, on the other hand, both ylides substitute a bromide ligand. Platinum(II) complexes with neutral, non stabilized ylide ligands have previously been obtained by addition of the phosphine to a halomethyl precursor, for instance the addition of excess $\mathrm{PPh}_{3}$ to cis- $\mathrm{Pt}(\mathrm{COD})\left(\mathrm{CH}_{2} \mathrm{I}\right)_{2}$ yielded cis-[ $\left.\mathrm{PtI}\left(\mathrm{PPh}_{3}\right)_{2}\left(\mathrm{CH}_{2} \mathrm{PPh}_{3}\right)_{2}\right]^{+} \mathrm{I}^{-}$, which was structurally characterized by $\mathrm{X}$-ray diffraction. ${ }^{22}$ Also, complex trans- $\left[\mathrm{PtI}\left(\mathrm{CH}_{2} \mathrm{PEt}_{3}\right)\left(\mathrm{PEt}_{3}\right)_{2}\right]^{+} \mathrm{I}^{-}$was obtained by reacting $\mathrm{Pt}\left(\mathrm{PEt}_{3}\right)_{3}$ and $\mathrm{CH}_{2} \mathrm{I}_{2}$, presumably via the intermediate oxidative addition product, $\operatorname{PtI}\left(\mathrm{CH}_{2} \mathrm{I}\right)\left(\mathrm{PEt}_{3}\right)_{2}$, which is further attacked by the released $\mathrm{PEt}_{3}{ }^{23}$

A possible reason for this unprecedented reactivity is related to the different coordination sphere and electronic environment around the $\mathrm{Pt}^{\mathrm{II}}$ center relative to the previous studies, which generally involved neutral complexes with phosphine ligands. 
Once a first halide ligand is replaced to generate a cationic $\left[\mathrm{Pt}(\mathrm{ylide}) \mathrm{X}\left(\mathrm{PR}_{3}\right)_{2}\right]^{+}$ complex, there is a choice between substitution of the second halide ligand or deprotonation at the $\alpha-\mathrm{CH}$ position of the already coordinated ylide ligand (see Scheme 2, $\mathrm{L}=\mathrm{PR}_{3}$ ). For the cationic complex ( $\mathrm{L}=$ neutral donor), the halide ligand is probably tightly bonded to Pt and the phosphorus atom of the already bonded ylide ligand has a high positive charge, exalting the acidity of the $\alpha-\mathrm{CH}$ bond and favoring deprotonation (transylidation). On the other hand, the anionic complex obtained when $\mathrm{L}=\mathrm{X}^{-}$(in the present case bromide) has reduced acidity at the ylide $\alpha-\mathrm{CH}$ bond and greater lability for the coordinated $\mathrm{X}^{-}$ligands, especially the one located trans to the ylide.

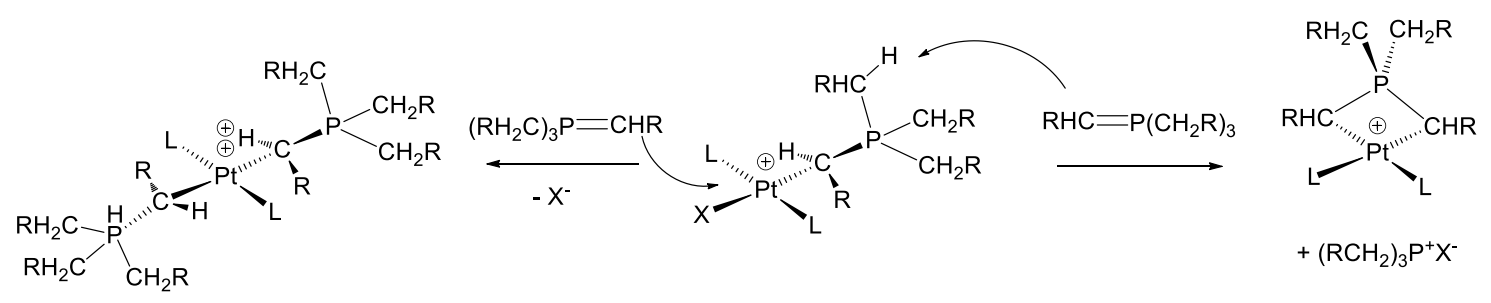

Scheme 2. Competing reaction pathways for the attack of a second ylide ligand to $\left[\operatorname{PtX}(\text { ylide })(\mathrm{L})_{2}\right]^{+}$.

The geometry of the trans-(R,S)-PtBr $2\left[\mathrm{CH}(n \mathrm{Pr}) \mathrm{P}(n \mathrm{Bu})_{3}\right]_{2}$ molecule, as revealed by an X-ray diffraction analysis, is shown in Figure 1. Relevant distances and angles are reported in Table 2. The molecule has crystallographically imposed inversion symmetry, 
with the Pt atom sitting on the inversion center and half of the molecule in the asymmetric unit. This is an unprecedented structural arrangement for $\mathrm{Pt}^{\mathrm{II}}$ ylide complexes. $^{24}$ The only other structurally characterized $\kappa^{1}$ phosphorus ylide complexes of $\mathrm{Pt}^{\mathrm{II}}$, according to the Cambridge Structural Database, are cationic complexes that contain only one ylide ligand (trans- $\left[\mathrm{PtI}\left(\mathrm{PEt}_{3}\right)_{2}\left(\mathrm{CH}_{2} \mathrm{PEt}_{3}\right)\right]^{+},{ }^{25}$ and cis$\left.\left[\mathrm{PtX}\left(\mathrm{PPh}_{3}\right)_{2}\left(\mathrm{CH}_{2} \mathrm{PPh}_{3}\right)\right]^{+}(\mathrm{X}=\mathrm{Cl}, \mathrm{I})^{26,27}\right)$ or two ylide ligands in a relative cis arrangement, cis-[PtI $\left.\left(\mathrm{PPh}_{3}\right)\left(\mathrm{CH}_{2} \mathrm{PPh}_{3}\right)_{2}\right]^{+} .22$ The complex described here, on the other hand, is neutral and features the two ylide ligands in a mutual trans arrangement. A related structure, which contains however a stabilized ylide ligand, is found for a palladium(II) complex, trans $-\mathrm{PdCl}_{2}\left[\mathrm{CH}(\mathrm{COPh})(\mathrm{P} n \mathrm{Bu})_{3}\right]_{2}{ }^{28}$ Like for those previously investigated ylide complexes, the P-C bond to the Pt-bonded $\mathrm{C}$ atom is slightly shorter than the other P-C bonds. The Pt-C11 distance is rather long relative to those observed in the above mentioned compounds (all being shorter than $2.1 \AA$ except for $2.12(2) \AA$ in cis- $\left.\left[\mathrm{PtI}\left(\mathrm{PPh}_{3}\right)_{2}\left(\mathrm{CH}_{2} \mathrm{PPh}_{3}\right)\right]^{+}\right)^{27}$. This is possibly related to the increased electron density at the metal center and the mutual trans arrangement of the strongly electron donating ylide ligands. 


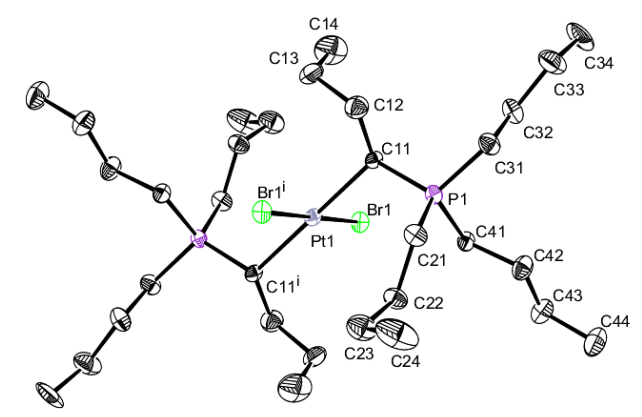

Figure 1. ORTEP view of the structure. Ellipsoids are drawn at the $30 \%$ probability level. $\mathrm{H}$ atoms have been omitted for clarity.

Table 2. Selected structural parameters (distances in $\AA$, angles in ${ }^{\circ}$ ) for the two diastereoisomers of trans $-\mathrm{PtBr}_{2}\left[\mathrm{CH}(n \mathrm{Pr})\left(\mathrm{P} n \mathrm{Bu}_{3}\right)\right]_{2}$. $^{\mathrm{a}}$

\begin{tabular}{|l|l|l|l|l|l|}
\hline & \multicolumn{3}{|c|}{ meso isomer } & \multicolumn{2}{c|}{$d l$ isomer } \\
\hline & X-Ray & gas & THF & gas & THF \\
\hline Pt-Br1 & $2.4560(11)$ & 2.532 & 2.531 & 2.527 & 2.532 \\
\hline Pt-C11 & $2.141(11)$ & 2.174 & 2.182 & 2.173 & 2.182 \\
\hline P1-C11 & $1.794(10)$ & 1.804 & 1.812 & 1.804 & 1.812 \\
\hline P1-C21 & $1.805(12)$ & 1.838 & 1.838 & 1.833 & 1.842 \\
P1-C31 & $1.813(12)$ & 1.857 & 1.852 & 1.861 & 1.857 \\
P1-C41 & $1.799(12)$ & 1.848 & 1.847 & 1.843 & 1.842 \\
\hline Br1-Pt-Br2 & 180.0 & 179.6 & 179.5 & 178.4 & 177.5 \\
\hline C11-Pt-C11' & 180.0 & 179.6 & 179.5 & 174.9 & 174.5 \\
\hline Br1-Pt-C11 & $91.9(3)$ & 92.5 & 92.4 & 91.8 & 91.8 \\
\hline Br1-Pt-C11 & $88.1(3)$ & 87.4 & 87.6 & 88.3 & 88.3 \\
\hline Pt-C11-P1 & $109.7(5)$ & 110.7 & 112.5 & 110.9 & 113.1 \\
\hline Pt-C11-C12 & $119.0(8)$ & 117.4 & 117.2 & 116.2 & 116.0 \\
\hline C11-P1-C21 & $112.8(6)$ & 110.8 & 110.6 & 114.0 & 113.9 \\
C11-P1-C31 & $111.1(5)$ & 112.4 & 112.2 & 113.6 & 113.1 \\
C11-P1-C41 & $113.2(5)$ & 114.2 & 114.3 & 110.6 & 110.7 \\
\hline
\end{tabular}

a All computed parameters related by pseudo-symmetry are given as an averaged single entry. Symmetry code (for the X-ray experimental structure): (') $-\mathrm{x}+1,-\mathrm{y}+1,-\mathrm{z}+1$. 
The most intriguing feature of this compound is the slow isomerization, interconverting the two diastereomers. Initially, the reaction yields a 1:1 mixture of the two isomers under kinetic control, as expected from statistical considerations since the trans arrangement of the two ylide ligands cannot lead to strong diastereoselection. However, the slight energetic difference (see DFT section below) leads to a subsequent slow re-equilibriation to give a final solution richer in the more stable meso isomer, which is also preferentially crystallized. This isomerization could in principle be caused by the presence of excess base, which could invert the configuration at the Pt-bonded $\mathrm{C}$ atom via reversible proton transfer steps, involving a chelated anionic ligand intermediate and also a cis isomeric form, as shown in Scheme 3 (path A).

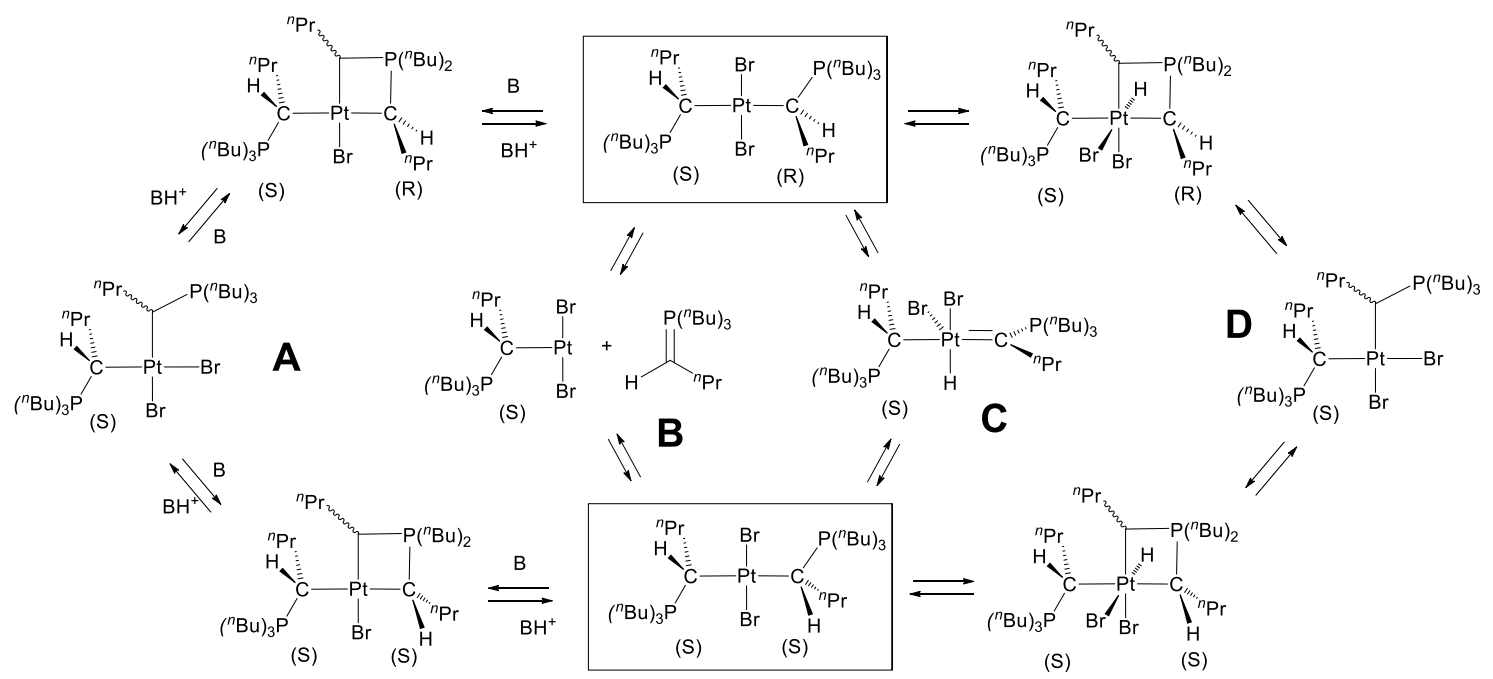

Scheme 3. Possible diastereoisomer interconversion mechanisms. 
However, when redissolving the isolated pure $(\mathrm{R}, \mathrm{S})$ crystals in $\mathrm{CDCl}_{3}$, a slow isomerization process still occurs. The ${ }^{195} \mathrm{Pt}\left\{{ }^{1} \mathrm{H}\right\}$ NMR spectrum recorded after 1 month on the solution prepared from the crystallized meso isomer is shown in Figure 2. This process cannot take place by pathway A, since no external base is present under these conditions. An alternative and simpler possibility consists of a dissociation/reassociation process (path B in Scheme 3). A dissociative exchange of non stabilized ylides, which are normally considered as strongly bonding ligands, is apparently unprecedented. A precedent for the interconversion of diastereoisomers was only reported, to the best of our knowledge, for complexes containing two stabilized chiral ylides, for instance for the similar palladium system trans $-\mathrm{PdCl}_{2}\left[\mathrm{CH}(\mathrm{COAr})\left(\mathrm{SMe}_{2}\right)\right]_{2}$, where equilibration took place over a few hours, ${ }^{29}$ and for a palladium compound containing the chelating phosphine-ylide $\mathrm{Ph}_{2} \mathrm{PCH}_{2} \mathrm{CH}_{2} \mathrm{PPh}_{2}=\mathrm{CHC}(\mathrm{O}) \mathrm{R}$ and a second asymmetric center in the chelating $o-\mathrm{C}_{6} \mathrm{H}_{4} \mathrm{CH}(\mathrm{Me}) \mathrm{NMe}_{2}$ ligand. ${ }^{30}$ In the latter case, the diastereomeric ratio was shown to change reversibly with temperature indicating rapid equilibrium. The occurrence of a dissociation for a non stabilized ylide ligand appears remarkable and may be facilitated in the present case by the strong mutual trans effect of two such ligands in relative trans position. Two other possibilities for the isomerization 
mechanism may be imagined, involving $\mathrm{C}-\mathrm{H}$ activation processes. In the first one, an $\alpha-$ $\mathrm{H}$ elimination from the ylide ligand could yield a 5-coordinate hydrido carbene intermediate, which could reverse to the opposite configuration at the $\mathrm{C}$ atom after stereochemical rearrangement of the Pt coordination sphere (Scheme 3, path C). The second one would entail a $\gamma-\mathrm{C}-\mathrm{H}$ oxidative addition to generate the chelating $\left[(\mathrm{CH} n \mathrm{Pr})_{2} \mathrm{P}(n \mathrm{Bu})_{2}\right]^{-}$ligand on a $\mathrm{Pt}^{\mathrm{IV}}$ hydrido intermediate, followed by the reductive elimination to yield the same $\mathrm{Pt}^{\mathrm{II}}$ cis isomer as in path $\mathrm{A}$, and then the reverse process to generate the opposite configuration at the $\mathrm{C}$ atom (Scheme 3, path $\mathrm{D}$ ).

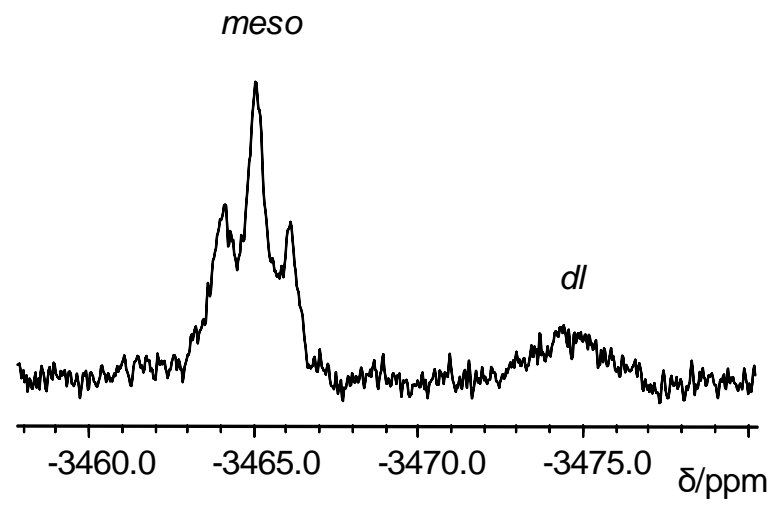

Figure 2. ${ }^{195} \mathrm{Pt}\left\{{ }^{1} \mathrm{H}\right\} \mathrm{NMR}$ spectrum of a $\mathrm{CDCl}_{3}$ solution of redissolved crystals of trans$(\mathrm{R}, \mathrm{S})-\mathrm{PtBr}_{2}\left[\mathrm{CH}(n \mathrm{Pr})\left(\mathrm{P} n \mathrm{Bu}_{3}\right)\right]_{2}$, after standing for 1 month at r.t.

DFT calculations have addressed the thermodynamic preference and have given indications about the isomerization mechanism. The calculations were carried out on the 
full model of the structurally characterized $(\mathrm{R}, \mathrm{S})$ isomer (no ligand simplification) and also on its $(\mathrm{R}, \mathrm{R})$ diastereoisomer. The molecular geometries were fully optimized both in the gas phase and in THF solution by the CPCM method (selected optimized values are collected in Table 2. Although no symmetry restrictions were used in the calculations, the energy minima were obtained for geometries with approximately $\mathrm{C}_{i}$ and $\mathrm{C}_{2}$ point group symmetry (shown in Figure 3 ) for the first coordination sphere in the $(R, S)$ and $(R, R)$ molecules, respectively. The ideal $C_{2}$ axis for the $(R, R)$ isomer runs through the Br-Pt-Br vector. This ideal symmetry is significantly broken only by the conformation adopted by the outermost $n \mathrm{Bu}$ and $n \mathrm{Pr}$ groups. Each pair of parameters related to each other by the pseudo-symmetry element in Table 2 display nearly equivalent values. The optimized parameters are very similar for the two diastereoisomers and are very close to those determined experimentally by X-ray diffraction for the meso isomer and all trends are reproduced, notably the slightly shorter $\mathrm{P}-\mathrm{C} 11$ distance relative to the $\mathrm{P}-\mathrm{C}$ distances involving the $n \mathrm{Bu}$ groups. Optimization in solvent yields substantially equivalent geometries to the gas phase. 


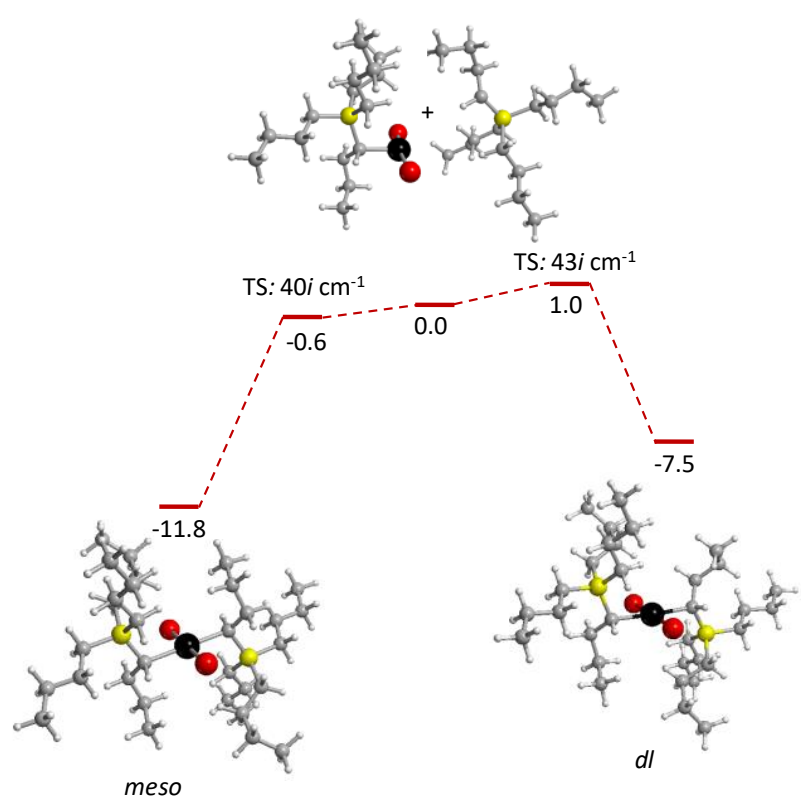

Figure 3. Views of the optimized geometries and relative energies computed at DFT/B3LYP/SDD(Pt)/6-31+G*(C,H,P,Br)/CPCM(THF) level of theory for the meso (left) and $d l$ (right) diastereomers of trans- $\mathrm{PtBr}_{2}\left[\mathrm{CH}(n \mathrm{Pr})\left(\mathrm{P} n \mathrm{Bu}_{3}\right)\right]_{2}$, and for the dissociative $\mathrm{PtBr}_{2}\left[\mathrm{CH}(n \mathrm{Pr})\left(\mathrm{P} n \mathrm{Bu}_{3}\right)\right]+n \mathrm{PrCH}=\mathrm{P} n \mathrm{Bu}_{3}$ (center).

The calculations indicate greater stability for the crystallographically characterized meso diastereoisomer. The stabilization relative to the $d l$ isomer on the $\Delta \mathrm{G}^{\mathrm{CPCM}}\left(\Delta \mathrm{E}_{\mathrm{ZPVE}}{ }^{\mathrm{CPCM}}\right)$ scale is $4.8(4.2) \mathrm{kcal} / \mathrm{mol}$ in the gas phase and $4.3(3.7) \mathrm{kcal} / \mathrm{mol}$ in solution. The reason for this energy difference is probably caused by less favorable van de Waals contacts between the $n \mathrm{Pr}$ and the $\mathrm{P}_{n} \mathrm{Bu}_{3}$ groups of the two different ylide ligands on the opposite sides of the molecule. These bulky groups prefer to occupy the space above and below the coordination plane (the $\mathrm{CH}$ bond of the Pt-bonded atom lies close to the coordination plane) and thus the meso form is better able to accommodate these groups further away from each other, as may be appreciated by inspecting a space 
filling model of the two optimized geometries, although the difference is not very large.

The calculated energy difference would lead to a meso/dl ratio of ca. $0.03 \%$ at equilibrium at room temperature, namely an unobservable relative amount, whereas a substantial amount of $d l$ isomer is generated as shown in Figure 2. However, DFT calculations are believed to yield relative energies for related systems within an accuracy of a few $\mathrm{kcal} / \mathrm{mol}$ (in our experience $\pm 2 \mathrm{kcal} / \mathrm{mol}$ when the two systems are very closely related as in the present case). Therefore, the computational result is not necessarily in disagreement with the experiment.

Following the geometry optimizations, the DFT approach was also used to estimate the ${ }^{195} \mathrm{Pt}$ chemical shifts for the two optimized geometries, yielding values of -28.8 ppm (R,S) and -37.6 ppm (R,R). Relative to the calculated chemical shift value for the $\mathrm{Na}_{2} \mathrm{PtCl}_{6}$ reference, these numbers become $-205.2 \mathrm{ppm}$ for the $(\mathrm{R}, \mathrm{S})$ isomer and -214.0 for the $(R, R)$ isomer. These values are quite far from those experimentally determined for the two compounds, probably because of the very different chemical nature of the complexes (neutral square planar $\mathrm{Pt}^{\mathrm{II}}$ for the bis(ylide) complexes, dianionic octahedral $\mathrm{Pt}^{\mathrm{IV}}$ for the reference) and limitations in the DFT accuracy for the calculation of the Pt shielding tensors. However, the chemical shift difference between the two isomers (ca. $10 \mathrm{ppm}$ ) matches quite well in both magnitude and sign with the 
experimentally observed one.

The calculations on the separate ylide and three-coordinate complex $\mathrm{PtBr}_{2}\left[\mathrm{CH}(n \mathrm{Pr})\left(\mathrm{P} n \mathrm{Bu}_{3}\right)\right]$ (intermediates of the dissociative isomerization mechanism, path B in Scheme 3) yield an energy only $11.8 \mathrm{kcal} / \mathrm{mol}$ higher than the more stable meso isomer $(7.5 \mathrm{kcal} / \mathrm{mol}$ higher than the $d l$ isomer), see Figure 3 . The energy of the transition state is not much higher, as could have been predicted a priori from the dissociative nature of the process. In fact, for the ylide dissociation from the more stable meso isomer this is found at even lower energy than the dissociation asymptote on the $\mathrm{CPCM}(\mathrm{THF})$ energy scale. In other words, the dissociative 4-coordinate intermediate has an essentially zero barrier for reassociation of the ylide and this perfectly justifies the initial formation a 50:50 diastereomeric mixture under kinetic control. Therefore, the results of the DFT calculations are consistent with the occurrence of this pathway. Concerning pathways $\mathrm{C}$ and $\mathrm{D}$, attempts to optimize the 5-coordinate $\mathrm{Pt}^{\mathrm{IV}}$ hydride intermediate of path $\mathrm{C}$ led to loss of the $\mathrm{Br}^{-}$ligand and optimization of a square planar geometry for $\left[\mathrm{PtHBr}\left\{\mathrm{CH}(n \mathrm{Pr})\left(\mathrm{P} n \mathrm{Bu}_{3}\right)\right\}\left\{\mathrm{C}(n \mathrm{Pr})\left(\mathrm{P} n \mathrm{Bu}_{3}\right)\right\}\right]^{-}$in close contact with the outer sphere $\mathrm{Br}^{-}$ion. Hence, the preference of $\mathrm{Pt}^{\mathrm{II}}$ for a square planar geometry induces loss of the weakest ligand in the coordination sphere. The energy of this intermediate species is $+32.5 \mathrm{kcal} / \mathrm{mol}$ relative to the starting meso compound (on the $\Delta \mathrm{G}$ scale in 
THF). The hydrido $\mathrm{Pt}^{\mathrm{IV}}$ intermediate of path $\mathrm{D}$, on the other hand, leads to smooth convergence to the expected pseudo-octahedral 6-coordinate geometry but is again found at very high energy relative to the meso compound $(+34.8 \mathrm{kcal} / \mathrm{mol}$ on the $\Delta \mathrm{G}$ scale in THF). Figures of these two high-energy minima are shown in Figure S3. In conclusion, the DFT study points strongly toward a dissociative mechanism for the diastereoisomer interconversion through the free non stabilized ylide.

\section{Conclusions}

We report here an unprecedented trans square planar bis(ylide) derivative of $\mathrm{Pt}^{\mathrm{II}}$ with a non stabilized ylide, generated by deprotonation of tetra- $n$-butylphosphonium. Given the central chirality of the Pt-bound $\mathrm{C}$ atom, meso and $d l$ diastereoisomers are generated by the synthesis as observed by ${ }^{31} \mathrm{P}$ and ${ }^{195} \mathrm{Pt} \mathrm{NMR}$, only the meso isomer being crystallized and structurally characterized. The observed slow interconversion of the two isomers in solution is suggested by a DFT study to take place via a dissociative mechanism with release of the non stabilized ylide. To the best of our knowledge, this is the first reported evidence for reversible dissociation of a non stabilized ylide, which is considered to be a strongly binding ligand, from a transition metal complex. The relative trans arrangement of two such ligands in the Pt coordination sphere is probably 
at the origin of this unexpected behavior.

Acknowledgements. We are grateful to the ANR (Agence Nationale de la Recherche, Grant No. NT09_442499), to the CNRS (Centre National de la Recherche Scientifique) and to the IUF (Institut Universitaire de France) for support of this work. This work was granted access to the HPC resources of CINES under the allocation 2010-086343 made by GENCI (Grand Equipement National de Calcul Intensif) and to the resources of the CICT (Centre Interuniversitaire de Calcul de Toulouse, project CALMIP). PD thanks the MENESR (Ministère de l'Éducation Nationale, de l'Enseignement Supérieur et de la Recherche, France) for a Ph.D. fellowship.

\section{References}

(1) Dub, P. A.; Rodriguez-Zubiri, M.; Daran, J.-C.; Brunet, J.-J.; Poli, R. Organometallics 2009, 28, 4764.

(2) Dub, P. A.; Poli, R. J. Am. Chem. Soc. 2010, 132, 13799.

(3) Dub, P. A.; Rodriguez-Zubiri, M.; Baudequin, C.; Poli, R. Green Chem. 2010, 1392.

(4) Dub, P. A.; Poli, R. J. Mol. Catal. A 2010, 324, 89.

(5) Dub, P. A.; Béthegnies, A.; Poli, R. Eur. J. Inorg. Chem. 2011, 5167.

(6) Dub, P. A.; Daran, J.-C.; Levina, V. A.; Belkova, N. V.; Shubina, E. S.; Poli, R. J. Organomet. Chem 2011, 696, 1174.

(7) Dub, P. A.; Béthegnies, A.; Poli, R. Organometallics 2012, 31, 294.

(8) Altomare, A.; Burla, M.; Camalli, M.; Cascarano, G.; Giacovazzo, C.; Guagliardi, A.; Moliterni, A.; Polidori, G.; Spagna, R. J. Appl. Cryst. 1999, 32, 115.

(9) Sheldrick, G. M. SHELXL97. Program for Crystal Structure refinement; University of Göttingen: Göttingen, Germany, 1997.

(10) Farrugia, L. J. J. Appl. Crystallogr. 1997, 32, 565. 
(12) Becke, A. D. J. Chem. Phys. 1993, 98, 5648.

(13) Lee, C. T.; Yang, W. T.; Parr, R. G. Phys. Rev. B 1988, 37, 785.

(14) Frisch, M. J.; Trucks, G. W.; Schlegel, H. B.; Scuseria, G. E.; Robb, M. A.; Cheeseman, J. R.; Scalmani, G.; Barone, V.; Mennucci, B.; Petersson, G. A.; Nakatsuji, H.; Caricato, M.; Li, X.; Hratchian, H. P.; Izmaylov, A. F.; Bloino, J.; Zheng, G.; Sonnenberg, J. L.; Hada, M.; Ehara, M.; Toyota, K.; Fukuda, R.; Hasegawa, J.; Ishida, M.; Nakajima, T.; Honda, Y.; Kitao, O.; Nakai, H.; Vreven, T.; Montgomery, J., J. A.; Peralta, J. E.; Ogliaro, F.; Bearpark, M.; Heyd, J. J.; Brothers, E.; Kudin, K. N.; Staroverov, V. N.; Kobayashi, R.; Normand, J.; Raghavachari, K.; Rendell, A.; Burant, J. C.; Iyengar, S. S.; Tomasi, J.; Cossi, M.; Rega, N.; Millam, N. J.; Klene, M.; Knox, J. E.; Cross, J. B.; Bakken, V.; Adamo, C.; Jaramillo, J.; Gomperts, R.; Stratmann, R. E.; Yazyev, O.; Austin, A. J.; Cammi, R.; Pomelli, C.; Ochterski, J. W.; Martin, R. L.; Morokuma, K.; Zakrzewski, V. G.; Voth, G. A.; Salvador, P.; Dannenberg, J. J.; Dapprich, S.; Daniels, A. D.; Farkas, Ö.; Foresman, J. B.; Ortiz, J. V.; Cioslowski, J.; Fox, D. J. Gaussian 09, Revision A.02, Gaussian, Inc.: Wallingford CT, 2009.

(15) Andrae, D.; Haussermann, U.; Dolg, M.; Stoll, H.; Preuss, H. Theor. Chim. Acta 1990, $77,123$.

(16) Wolinski, K.; Hinton, J. F.; Pulay, P. J. Am. Chem. Soc. 1990, 112, 8251.

(17) Schmidba.H; Buchner, W.; Scheutzo.D Chemische Berichte-Recueil 1973, 106, 1251.

(18) Weleski, E. T.; Silver, J. L.; Jansson, M. D.; Burmeister, J. L. J. Organomet. Chem. $1975,102,365$.

(19) Schmidbaur, H. Pure Appl. Chem. 1980, 52, 1057.

(20) Illingsworth, M. L.; Teagle, J. A.; Burmeister, J. L.; Fultz, W. C.; Rheingold, A. L. Organometallics 1983, 2, 1364.

(21) Teagle, J. A.; Burmeister, J. L. Inorg. Chim. Acta 1986, 118, 65.

(22) Hoover, J. F.; Stryker, J. M. Organometallics 1988, 7, 2082.

(23) Kermode, N. J.; Lappert, M. F.; Skelton, B. W.; White, A. H.; Holton, J. Chem. Commun. 1981, 698.

(24) Urriolabeitia, E. P. In Transition Metal Complexes of Neutral Eta1-Carbon Ligands; Chauvin, R., Canac, Y., Eds. 2010; Vol. 30, p 15.

(25) Kermode, N. J.; Lappert, M. F.; Skelton, B. W.; White, A. H.; Holton, J. J. Organomet. Chem. 1982, 228, C71.

(26) Engelter, C.; Moss, J. R.; Niven, M. L.; Nassimbeni, L. R.; Reid, G. J. Organomet. Chem. 1982, 232, C78.

(27) Engelter, C.; Moss, J. R.; Nassimbeni, L. R.; Niven, M. L.; Reid, G.; Spiers, J. C. J. 
Organomet. Chem. 1986, 315, 255.

(28) Albanese, J. A.; Rheingold, A. L.; Burmeister, J. L. Inorg. Chim. Acta 1988, 150, 213.

(29) Bravo, P.; Fronza, G.; Ticozzi, C.; Gaudiano, G. J. Organomet. Chem. 1974, 74, 143.

(30) Falvello, L. R.; Fernandez, S.; Navarro, R.; Urriolabeitia, E. P. New Journal of Chemistry 1997, 21, 909. 


\section{Table of Content Graphic}

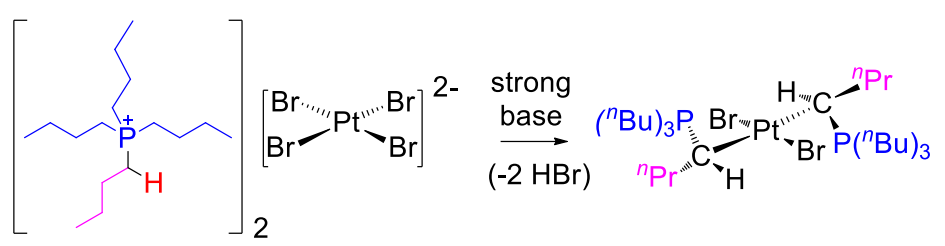

\section{Synopsis}

Deprotonation of tetra- $n$-butylphosphonium in association with the tetrabromoplatinate(II) dianion yields a unique example of a trans-bis(ylide) complex of $\mathrm{Pt}^{\mathrm{II}}$ with non stabilized phosphorus ylide ligands. 